\title{
PENGARUH Paecilomyces sp. PADA BERBAGAI BAHAN ORGANIK TERHADAP KETAHANAN DAN PRODUKSI PADI GOGO
}

\section{The effect of Paecilomyces sp. on various organic matters on resistance and production of upland rice}

\author{
Muhammad Botek ${ }^{a *}$, La Ode Jabuddin ${ }^{b}$, Rahayu Endah Purwantib ${ }^{b}$ Pertiwi Syarni ${ }^{b}$, Rahayu \\ Mallarangeng ${ }^{a}$, dan Syair ${ }^{a}$ \\ aJurusan Proteksi Tanaman, Fakultas Pertanian, Universitas Halu Oleo, Kendari, Indonesia \\ bJurusan Agribisnis, Fakultas Pertanian, Universitas Halu Oleo, Kendari, Indonesia \\ Doi: 10.37195/jac.v2i2.91
}

\section{*KORESPONDENSI \\ Telepon: +62-821-8999-0404 \\ E-mail: botekronta@gmail.com \\ JEJAK PENGIRIMAN}

Diterima: 27 Des 2019

Revisi Akhir: 23 Agu 2020

Disetujui: 27 Agu 2020

\section{KEYWORDS}

Paecilomyces sp., Organic matter, Upland rice

\section{KATA KUNCI}

Paecilomyces sp., Bahan organik, Padi gogo

\section{ABSTRACT}

Paecilomyces sp. is an endophytic fungus that interacts positively with plants and potentially to protect plants from pathogens. This study aims were to evaluate the role of the fungus Paecilomyces sp. and the use of organic matter on the resistance and generative phase of upland rice in the field. This study used a Randomized Block Design in a factorial pattern with 2 factors: the first factor is the use of organic matter consisting of: cow manure (B1), compost fertilizer (B2) and the second factor is the application of endophytic fungi consisting of: without application of Paecilomyces sp. and without fungicide (TO), application of fungicide (T1), application of Paecilomyces sp. in the form of powder (T2) and the application of Paecilomyces sp. in the form of suspension (T3). Data observations were analyzed used variance analysis and continued with the Duncan Multiple Range Test (DMRT). The result showed that a combination of cow manure and application of Paecilomyces sp. in powder form (B1T2) provides the best response to increasing the resistance of upland rice, the number of grains, panicle length, and upland rice production.

Cendawan Paecilomyces sp. merupakan salah cendawan endofit yang berinteraksi positif dengan tanaman dan berpotensi melindungi tanaman dari patogen. Penelitian ini bertujuan mengkaji peran cendawan Paecilomyces sp dan penggunaan bahan organik terhadap ketahanan dan fase generatif padi gogo di lapangan. Penelitian ini menggunakan Rancangan Acak Kelompok (RAK) dalam pola faktorial dengan 2 faktor yaitu faktor pertama adalah penggunaan bahan organik terdiri dari: Pupuk organik kotoran sapi (B1), pupuk kompos (B2) dan faktor kedua adalah aplikasi cendawan endofit yang terdiri dari: tanpa aplikasi Paecilomyces sp dan tanpa fungisida (T0), aplikasi fungisida (T1), aplikasi Paecilomyces sp. dalam bentuk powder (T2) dan aplikasi Paecilomyces sp. dalam bentuk suspensi (T3). Data hasil pengamatan dianalisis sidik ragam dan dilanjutkan dengan uji jarak berganda duncan (UJBD). Kombinasi pupuk organik kotoran sapi dan aplikasi Paecilomyces sp. dalam bentuk powder (B1T2) memberikan respon terbaik terhadap ketahanan, jumlah bulir, panjang malai dan produksi padi gogo. 


\section{PENDAHULUAN}

Padi (Oryza sativa L.) merupakan komoditas pangan utama sebagian besar penduduk Indonesia. Kebutuhan beras nasional terus mengalami peningkatan dari tahun ke tahun dengan asumsi pertumbuhan penduduk $2 \%$ per tahun. Sebaliknya produktivitas padi sawah sebagai penyuplai kebutuhan beras tidak mampu mengimbangi laju peningkatan penduduk (Sitohang, 2014). Di sisi lain, kebutuhan beras dapat terpenuhi dengan mengembangkan padi lokal yang dapat beradaptasi dengan lingkungan yang kering di beberapa daerah, termasuk Sulawesi Tenggara. Meskipun dengan potensi plasma nutfah padi gogo yang beragam dan lahan yang ada, produktivitas padi gogo Sulawesi Tenggara masih tergolong rendah dan cenderung menurun sejak tahun 2014. Produktivitas padi gogo Sulawesi Tenggara mencapai 31,48 Kw/ha yang terus menurun hingga tahun 2017 yang hanya mencapai 26,57 Kw/ha (BPS, 2018).

Kebiasaan petani lokal Sulawesi Tenggara sangat primitif, hanya mengandalkan daya dukung lahan secara alamiah tanpa melakukan input teknologi baik pemenuhan unsur hara maupun pengelolaan hama dan penyakit tanaman. Ketersediaan hara dan bahan organik yang rendah juga menjadi tantangan dalam budidaya padi gogo di lahan kering. Upaya yang dilakukan dalam meminimalisir tantangan tersebut adalah pemberian pupuk. Pupuk yang dapat diaplikasikan ke tanaman meliputi pupuk organik dan anorganik. Sari, Ete, dan Usman (2017) menjelaskan bahwa dalam budidaya padi gogo sebaiknya pemupukan harus memadukan antara pupuk anorganik dan pupuk organik. Pemberian pupuk organik baik berupa pupuk kandang, pupuk kompos maupun pupuk hijau dapat meningkatkan kesehatan tanah yang terdiri dari sifat fisik, kimia dan biologi. Sedangkan pemberian pupuk anorganik dapat memenuhi kebutuhan hara bagi tanaman dalam waktu yang singkat.

Penyakit blas pada padi disebabkan oleh cendawan Pyricularia oryzae (teleomorph: Magnaporthe oryzae Couch) merupakan penyakit penting dan menimbulkan kerusakan terbesar pada tanaman padi gogo (Couch \& Kohn, 2002). Penyakit ini menyebar di seluruh dunia dan terjadi pada seluruh area produksi padi yang dapat sangat merusak ketika kondisi lingkungan cocok. Perkembangan dan keparahan penyakit dipengaruhi beberapa faktor diantaranya lokasi, kondisi cuaca serta praktek pengelolaan penanaman. Kehilangan hasil akibat penyakit blas pada padi dari suatu daerah di dunia diperkirakan berkisar antara 50-100\%. Hal ini diperkirakan bahwa tiap tahunnya penyakit ini menghancurkan padi yang akan cukup dimakan oleh lebih dari 60 juta orang. Kehilangan hasil secara ekonomi tidak dapat terhitung, tetapi beberapa data menunjukkan nilainya lebih dari 70 milyar dolar pada beberapa negara di Asia (Scheuermann, Andrade, Wickert, Raimondi, \& Marschalek, 2012).

Cendawan endofit merupakan salah satu mikroorganisme yang potensial dalam meningkatkan ketahanan padi gogo. Clay (1998) dalam Ariyanto, Abadi, dan Djauhari (2013) menyebutkan bahwa cendawan endofit terdapat dalam semua jaringan tumbuhan mulai dari daun, bunga, ranting ataupun akar tumbuhan. Interaksi antara cendawan endofit dan tanaman inang dapat memberikan dampak yang saling menguntungkan (simbiosis mutualisme). Cendawan endofit dapat menginfeksi tanaman pada jaringan tertentu dan mampu menghasilkan toksin, enzim serta antibiotika. Asosiasi beberapa cendawan endofit dengan tumbuhan inangnya mampu melindungi beberapa tumbuhan inangnya dari beberapa patogen virulen, kondisi ekstrim maupun herbivora.

Salah satu cendawan endofit yang berpotensi melindungi tanaman inangnya dari serangan berbagai patogen adalah Paecilomyces sp. Amaria, Taufiq, dan Harni (2013) menyeleksi dan mengidentifikasi 12 isolat antagonis yang terdiri dari 8 isolat rhizosfer dan 4 isolat endofit yang di dalamnya termasuk Paecilomyces lilannicus. Fauziah dan Rohdiana (2016) melaporkan bahwa penggunaan Paecilomyces sp. cukup kompatibel dengan penggunaan pestisida yang persentase sporanya bisa mencapai $13,77 \%$. Dalam aplikasinya di lapangan, beberapa cendawan endofit dapat efektif diaplikasikan dalam formulasi cair (Herlinda, Mulyati, \& Suwandi, 2008) dan dibiakan dalam bentuk formulasi granula (Oktariana, Wijaya, \& Febrianto, 2012). 


\section{BAHAN DAN METODE}

\section{Bahan}

Bahan yang digunakan dalam penelitian ini adalah benih padi gogo, pupuk organik, dolomit, kotoran sapi, pupuk Phonska, EM4, dan Paecilomyces sp.

\section{Desain Penelitian}

Penelitian ini menggunakan rancangan faktorial dalam pola Rancangan Acak Kelompok (RAK) yang terdiri dari 2 faktor. Faktor pertama adalah penggunaan bahan organik, yaitu: pupuk organik kotoran sapi (B1) dan pupuk kompos (B2)dan Faktor kedua adalah aplikasi cendawan endofit, yaitu:tanpa aplikasi cendawan endofit (T0), aplikasi fungisida (T1), aplikasi Paecilomyces sp dalam bentuk powder (T2) dan aplikasi Paecilomyces sp. dalam bentuk suspensi (T3). Dengan demikian perlakuan yang diuji sebanyak 8 kombinasi perlakuan. Setiap perlakuan diulang 4 kali, sehingga terdapat 32 unit percobaan.

\section{Penyiapan Cendawan Endofit}

Cendawan endofit yang digunakan adalah Paecilomyces sp. yang telah diperbanyak pada media beras ketan (powder) dan diformulasikan dalam bentuk cair (suspensi). Aplikasi cendawan endofit Paecilomyces sp. dilakukan bersamaan dengan penanaman benih padi gogo dengan takaran 10 gram perlubang tanam. Aplikasi Paecilomyces sp. dilakukan pada saat perendaman benih, yaitu koloni yang tumbuh pada media PDA (Potato Dextrose Agar) disuspensikan dalam aquades steril, kemudian dimasukkan ke dalam wadah yang berisikan benih yang telah dicuci dengan air steril sebanyak 3 kali selama 24 jam.

\section{Pengolahan Lahan}

Pengolahan lahan diawali dengan pembersihan lahan dari guma dan sisa-sisa tanaman dengan menggunakan parang. Pengolahan tanah dilakukan sebanyak dua kali, yang pertama tanah diolah seluruhnya dengan menggunakan hand traktor dalam bentuk bongkahan tanah sampai kedalaman 20 $\mathrm{cm}$. Pengolahan kedua, menghancurkan bongkahan tanah menjadi lebih halus dengan menggunakan cangkul. Selanjutnya dibuat petak perlakuan dengan ukuran $3 \mathrm{~m} \times 1,5 \mathrm{~m}$.

\section{Pengapuran dan Penambahan Bahan Organik}

Pengapuran dan pemberian bahan organik dilakukan untuk memperbaiki sifak fisik tanah, kimia dan biologi tanah. Pengapuran dan pemberian bahan organik dilaplikasikan dengan dosis 1,08 kg.petak ${ }^{-1}$ atau setara 2,40 ton.ha ${ }^{-1}$ untuk kapur dan 5,57 kg.petak ${ }^{-1}$ atau setara 12,38 ton.ha $^{-1}$ untuk bahan organik. Aplikasi kapur dan bahan organik dilakukan satu minggu sebelum penanaman.

\section{Penanaman}

Penanaman dilakukan secara tradisional dengan menggunakan tugal dan metode tanam benih langsung. Jarak tanam padi gogo yaitu $30 \times 25 \mathrm{~cm}$ dan benih padi yang ditabur berisi 5 butir benih perlubang.

\section{Pemeliharaan}

Pemeliharaan padi gogo yang dilakukan meliputi penyulaman, pembersihan gulma, dan pengendalian hama. Penyulaman dilakukan untuk tanaman yang memperlihatkan tandatanda pertumbuhan yang terhambat (mati) atau hilangnya bibit akibat dimakan oleh hama, dengan cara mengganti dengan tanaman sulaman. Penyiangan gulma yang tumbuh disekitar tanaman dilakukan secara manual setiap hari.

\section{Pemanenan}

Panen dilakukan apabila tanaman sudah menunjukkan kematangan fisiologi sudah mencapai $80-90 \%$ yang ditandai bulir berwarna kuning keemasan (kultivar/varietas yang bulirnya berwarna kuning) dan ujung daun bendera mulai berwarna coklat/mengering.

\section{Parameter Pengamatan}

Parameter pengamatan dalam penelitian ini sebagai berikut:

1. Keparahan penyakit blas diamati pada akhir pengamatan dengan rumus :

$$
\mathrm{KP}=\frac{\sum_{\mathrm{i}=1}^{\mathrm{n}}\left(\mathrm{n}_{\mathrm{i}} \times \mathrm{v}_{\mathrm{i}}\right)}{(\mathrm{N} \times \mathrm{Z})} \times 100
$$

Keterangan: $\mathrm{KP}=$ Keparahan Penyakit (disease severity), $\mathrm{n}_{\mathrm{i}}=$ jumlah daun dalam setiap kategori serangan, $\mathrm{v}_{\mathrm{i}}=$ nilai numerik 
setiap kategori serangan, $Z$ = nilai numerik kategori serangan tertinggi, $\mathrm{N}=$ jumlah daun yang diamati. Nilai numerik kategori serangan diukur dengan melihat perbedaan tingkat keparahan serangan patogen pada daun tanaman yaitu: 0 = tidak ada serangan, 1 = luas daun terserang kurang dari 1\%, $3=$ luas daun terserang $1-5 \%, 5$ = luas daun terserang 6-25\%, 7 = luas daun terserang 26-50\%, dan 9 = luas daun terserang 51$100 \%$ (Silitonga, Somantri, Daradjat, \& Kurniawan, 2003).

2. Panjang malai, diukur pada saat tanaman telah mengeluarkan malai mulai dari leher sampai ujung malaipada 3 sampel malai per rumpun.

3. Jumlah bulir permalai, dihitung dari 3 sampel malai per rumpun.

4. Hasil gabah kering, dihitung dengan menggunakan metode ubinan yang dikonversi dalam satuan hektar yang dapat dilakukan dengan menggunakan rumus:

Hasil gabah kering $=\frac{\text { Luas lahan } 1 \text { ha }}{\text { Luas Ubinan }} \times$ Bobot hasil ubinan

\section{HASIL DAN PEMBAHASAN Keparahan Penyakit Blas}

Hasil analisis sidik ragam menunjukkan bahwa terdapat pengaruh interaksi antara bahan organik dan cendawan endofit terhadap keparahan penyakit blas pada padi gogo. Kombinasi pupuk kotoran sapi dan aplikasi fungisida (B1T1) memberikan respon keparahan penyakit blas terendah pada padi gogo dengan rata-rata keparahan penyakit adalah $34,56 \%$. Keparahan penyakit tertinggi terdapat pada kombinasi pupuk kompos dan tanpa aplikasi fungisida dan cendawan endofit (B2T0) dengan rata-rata keparahan penyakit adalah 53,08\% (Tabel 1).

Paecilomyces sp. dalam bentuk powder yang diaplikasikan pada perakaran tanaman padi gogo mampu beradaptasi dengan baik pada bahan organik kotoran sapi. Hal ini ditunjukkan keparahan penyakit blas padi gogo yang diinokulasi Paecilomyces sp. dalam powder dan kotoran sapi di perakaran tanaman yang berbeda tidak nyata dengan aplikasi fungisida. Paul (2007) melaporkan bahwa, akar tanaman merupakan organ tanaman yang terkolonisasi cendawan dibandingkan dengan batang dan daun tanaman. Jaringan akar tanaman dan bahan organik menyediakan habitat dan nutrisi yang diperlukan oleh cendawan endofit termasuk Paecilomyces sp. Interaksi antara tanaman dan cendawan endofit diinisiasi oleh tanaman dengan mensekresikan eksudat akar sehingga cendawan endofit dapat berkembang di daerah perakaran tanaman (rhizosfer). Cendawan Paecilomyces sp. yang mengkoloni perakaaran tanaman mengakibatkan terjadinya modifikasi lingkungan fisik dan kimia tanah yang akan mempengaruhi tanaman padi gogo.

Mekanisme ketahanan tanaman oleh cendawan endofit dapat dilakukan dilakukan dengan 2 cara yaitu mekanisme langsung dan mekanisme tidak langsung. Mekanisme langsung dapat terjadi dengan kompetisi, antibiosis dan lisis, sedangkan mekanisme tidak langsung dapat terjadi melalui induksi ketahanan tanaman dan meningkatkan pertumbuhan tanaman. Penurunan keparahan penyakit blas pada padi gogo terinfestasi Paecilomyces sp., diduga disebabkan karena Paecilomyces sp. dapat melakukan mekanisme ketahanan tanaman, baik langsung maupun tidak langsung. Assad, Taufik, Gusnawaty, dan Asniah (2017) berhasil mengisolasi cendawan endofit dan melaporkan isolat cendawan endofit Paecilomyces sp. EP1 berpotensi sebagai agen pengendali patogen yang ramah lingkungan. Lebih lanjut Sainul, Taufik, Gusnawaty, Khaeruni, Hasid, dan Botek (2019) melaporkan bahwa Paecilomyces sp. dapat meningkatkan ketahanan padi gogo terhadap penyakit blas serta mereduksi penggunaan pupuk anorganik.

\section{Panjang Malai}

Cendawan endofit secara mandiri berpengaruh nyata terhadap panjang malai padi gogo. Aplikasi fungisida (T1) memberikan respon panjang malai tertinggi pada padi gogo dengan rata-rata panjang malai adalah 35,15 cm yang berbeda nyata dengan tanpa aplikasi fungisida dan cendawan endofit (T0) dengan rata-rata panjang malai adalah $32,88 \mathrm{~cm}$ (Tabel 2).

Aplikasi Paecilomyces sp. (T2 dan T3) memberikan respon yang berbeda tidak nyata dengan aplikasi fungisida (T1) terhadap panjang malai padi gogo. Hal ini diduga peranan cendawan endofit sebagai biofertilizer menjadi faktor yang berperan dalam fase generatif tanaman padi gogo. Koloni 
cendawan Paecilomyces sp. di perakaran tanaman menyebabkan terjadinya perubahan lingkungan fisik dan kimia tanah yang akan mempengaruhi tanaman padi gogo. Perubahan kimia dapat terjadi sebagai akibat dari proses humifikasi maupun mineralisasi bahan organik menjadi bentuk yang siap diserap oleh tanaman. Selain itu keberadaan mikroba yang mengkoloni perakaran tanaman mampu melakukan fiksasi nitrogen bebas menjadi bentuk yang dapat dimanfaatkan oleh tanaman. Irawati, Hartati, dan Windriyati (2014) melaporkan beberapa cendawan endofit dari biji dan tanaman padi memiliki potensi dalam meningkatkan ketahanan tanaman terhadap stress kekeringan dan pemicu pertumbuhan tanaman termasuk panjang malai. Lebih lanjut, Sainul et al. (2019) melaporkan bahwa pemanfaatan Paecilomyces sp. pada padi gogo dapat meningkatkan pertumbuhan tanaman dan mengurangi penggunaan pupuk anorganik hingga $25 \%$.

Tabel 1. Pengaruh interaksi antara cendawan endofit dan berbagai bahan organik terhadap keparahan penyakit blas pada padi gogo (\%)

\begin{tabular}{|c|c|c|c|c|c|c|c|}
\hline \multirow{2}{*}{ Bahan Organik } & \multicolumn{6}{|c|}{ Cendawan Endofit } & \multirow{2}{*}{ UJBD 0,05} \\
\hline & T0 & $\mathrm{T} 1$ & & $\mathrm{~T} 2$ & & T3 & \\
\hline B1 & $\begin{array}{cc}49,58 & b \\
p & \end{array}$ & $\begin{array}{c}34,56 \\
\mathrm{R}\end{array}$ & $\mathrm{b}$ & $\begin{array}{c}35,96 \\
r\end{array}$ & B & $\begin{array}{cc}39,41 & b \\
q & \end{array}$ & $\begin{array}{l}2=2,12 \\
3=2,23\end{array}$ \\
\hline B2 & $\begin{array}{cc}53,08 & a \\
p & \\
\end{array}$ & $\begin{array}{c}39,06 \\
\mathrm{~S}\end{array}$ & a & $\begin{array}{c}47,01 \\
r\end{array}$ & A & $\begin{array}{cc}50,07 & a \\
q & \end{array}$ & $\begin{array}{l}3=2,23 \\
4=2,29\end{array}$ \\
\hline
\end{tabular}

Ket.: Angka-angka yang diikuti oleh huruf yang sama pada huruf kecil (baris) dan huruf kapital (kolom) pada perlakuan yang sama menunjukkan tidak berbeda nyata berdasarkan taraf kepercayaan $95 \%$

Tabel 2. Pengaruh mandiri cendawan endofit terhadap panjang malai padi gogo $(\mathrm{cm})$

\begin{tabular}{cccccc}
\hline \multirow{2}{*}{ Bahan Organik } & \multicolumn{4}{c}{ Cendawan Endofit } & \multirow{2}{*}{ Rerata } \\
\cline { 2 - 4 } & T0 & T1 & T2 & T3 $n n$ & \\
\hline B1 & 32,88 & 35,70 & 35,15 & 34,58 & 34,58 \\
B2 & 32,88 & 34,60 & 34,63 & 34,30 & 34,10 \\
\hline Rerata & $32,88^{\mathrm{q}}$ & $35,15^{\mathrm{p}}$ & $34,89^{\mathrm{pq}}$ & $34,44^{\mathrm{pq}}$ & \\
\hline UJBD $_{0,05}$ & $2=2,04$ & $3=2,15$ & $4=2,22$ & & \\
\hline
\end{tabular}

Ket.: Angka-angka yang diikuti oleh huruf yang sama pada huruf kecil (baris) dan huruf kapital (kolom) pada perlakuan yang sama menunjukkan tidak berbeda nyata berdasarkan taraf kepercayaan $95 \%$

Tabel 3. Pengaruh mandiri bahan organik cendawan endofit terhadap jumlah bulir padi gogo (bulir)

\begin{tabular}{ccccccc}
\hline \multirow{2}{*}{ Bahan Organik } & \multicolumn{9}{c}{ Cendawan Endofit } & \multirow{2}{*}{ Rerata } & \multirow{2}{*}{ UJBD $_{0,05}$} \\
\cline { 2 - 4 } & T0 & T1 & T2 & T3 & & \\
\hline B1 & 94,79 & 106,85 & 106,17 & 104,08 & $102,97^{\mathrm{a}}$ & $2=8,42$ \\
B2 & 84,63 & 94,52 & 93,98 & 93,28 & $91,60^{\mathrm{b}}$ & \\
\hline Rerata & $89,71^{\mathrm{q}}$ & $100,69^{\mathrm{p}}$ & $100,08^{\mathrm{p}}$ & $98,68^{\mathrm{p}}$ & & \\
\hline UJBD $_{0,05}$ & $2=8,42$ & $3=8,85$ & $4=9,13$ & & &
\end{tabular}

Ket.: Angka-angka yang diikuti oleh huruf yang sama pada huruf kecil (baris) dan huruf kapital (kolom) pada perlakuan yang sama menunjukkan tidak berbeda nyata berdasarkan taraf kepercayaan $95 \%$

Tabel 4. Pengaruh mandiri bahan organik cendawan endofit terhadap hasil gabah kering padi gogo (ton.ha ${ }^{-1}$ )

\begin{tabular}{|c|c|c|c|c|c|c|}
\hline \multirow{2}{*}{ Bahan Organik } & \multicolumn{4}{|c|}{ Cendawan Endofit } & \multirow{2}{*}{ Rerata } & \multirow{2}{*}{ UJBD 0,0} \\
\hline & T0 & $\mathrm{T} 1$ & $\mathrm{~T} 2$ & T3 & & \\
\hline B1 & 3,23 & 4,00 & 3,84 & 3,67 & $3,69^{\mathrm{a}}$ & $2=0,33$ \\
\hline B2 & 3,05 & 3,44 & 3,42 & 3,27 & $3,29^{b}$ & \\
\hline Rerata & $3,14^{q}$ & $3,72^{p}$ & $3,63^{p}$ & $3,47 \mathrm{pq}$ & & \\
\hline $\mathrm{UJBD}_{0,05}$ & $2=0,46$ & $3=0,49$ & $4=0,50$ & & & \\
\hline
\end{tabular}

Ket.: Angka-angka yang diikuti oleh huruf yang sama pada huruf kecil (baris) dan huruf kapital (kolom) pada perlakuan yang sama menunjukkan tidak berbeda nyata berdasarkan taraf kepercayaan 95\% 


\section{Jumlah Bulir}

Hasil analisis sidik ragam menunjukkan bahwa bahan organik dan cendawan endofit berpengaruh secara mandiri terhadap jumlah bulir padi gogo. Pupuk kotoran sapi (B1) memberikan respon terbaik terhadap jumlah bulir padi gogo yang berbeda nyata dengan pupuk kompos (B2) dengan rata-rata jumlah bulir adalah 102,97 bulir. Aplikasi fungisida (T1) memberikan respon jumlah bulir tertinggi yang berbeda tidak nyata dengan aplikasi cendawan endofit (T2 dan T3) dengan rata-rata jumlah bulir adalah 100,69 bulir (Tabel 3).

Paecilomyces sp. memberikan respon jumlah bulir yang berbeda tidak nyata dengan aplikasi fungisida. Peranan Paecilomyces sp. sebagai bioferlizer didiuga berperan langsung terhadap pengisian bulir padi gogo secara langsung. Cendawan endofit yang diinokulasikan dapat meningkatkan pertumbuhan tanaman (Irawati et al., 2014). Selain itu secara tidak langsung infeksi patogen P. oryzae diduga mempengaruhi fase pengisian bulir. Yuliani dan Maryana (2014), memaparkan bahwa infeksi Pyricularia sp. sebelum pengisian bulir dapat menghambat proses pengisian bulir bahkan menyebabkan bulir hampa. Penambahan bahan organik dapat merubah sifat fisik, kimia dan biologi tanah. Perbedaan yang terjadi antara pupuk kandang sapi dan pupuk kompos, diduga pupuk kandang sapi sudah terdekomposisi sempurna sehingga memberi respon yang lebih baik pada padi gogo. Taha, Mahmoud, El-Damaty, dan Abd El-Hafez (1969) berpendapat bahwa, bahan yang terurai (terdekomposisi) cepat dapat menyediakan unsur hara yang dibutuhkan tanaman dengan cepat juga.

\section{Hasil Gabah Kering}

Hasil analisis sidik ragam menunjukkan bahwa bahan organik dan cendawan endofit berpengaruh secara mandiri terhadap hasil gabah kering padi gogo. Pupuk kotoran sapi (B1) memberikan respon terbaik terhadap hasil gabah kering padi gogo yang berbeda nyata dengan pupuk kompos (B2) dengan rata-rata hasil gabah kering adalah 3,69 ton.ha ${ }^{-1}$. Aplikasi fungisida (T1) memberikan respon hasil gabah kering tertinggi yang berbeda tidak nyata dengan aplikasi cendawan Paecilomyces sp dalam bentuk powder (T2) dengan rata-rata hasil gabah kering adalah 3,72 ton.ha ${ }^{-1}$ (Tabel 4).

Hasil gabah kering mengambarkan akumulasi semua fase tanaman baik fase vegetatif, ketahanan maupun fase generatif tanaman. Pupuk kandang sapi memberikan respon hasil gabah kering terbaik yang diduga komposisi bahan organiknya sudah terurai dengan sempurna sehingga memberikan dampak langsung ke tanaman. Paecilomyces sp. memberikan hasil gabah kering yang berbeda tidak nyata dengan aplikasi fungisida. Hal ini memperkuat pernyataan Sainul et al. (2019), bahwa Paecilomyces sp. dapat meningkatkan produksi gogo.

\section{KESIMPULAN}

Paecilomyces sp. dan bahan organik berpengaruh terhadap ketahan dan produksi padi gogo. Kombinasi pupuk organik kotoran sapi dan aplikasi Paecilomyces sp. dalam bentuk powder (B1T2) memberikan respon terbaik terhadap ketahanan, jumlah bulir, panjang malai dan produksi padi gogo.

\section{DAFTAR PUSTAKA}

Amaria, W., Taufiq, E., \& Harni, R. (2013). Seleksi dan identifikasi jamur antagonis sebagai agens hayati jamur akar putih Rigidoporus microporus pada tanaman karet. Buletin Riset Tanaman Rempah dan Aneka Tanaman Industri, 4(1), 55-64.

Ariyanto, E. F., Abadi, A. L., \& Djauhari, S. (2013). Keanekaragaman jamur endofit pada daun tanaman padi (Oryza sativa L.) dengan sistem pengelolaan hama terpadu (PHT) dan konvensional di Desa Bayem, Kecamatan Kasembon, Kabupaten Malang. Jurnal HPT, 1(2), 37-51.

Assad, M., Taufik, M., Gusnawaty, H. S., \& Asniah. (2017). Isolation, identification and ability of endophytic fungi in stimulating cocoa seed germination. Int. J. Biosci., 10(1), 270-278.

BPS. (2018). Sulawesi Tenggara dalam angka. Retrieved 2019, from https://sultra.bps. go.id/

Couch, B. C., \& Kohn, L. M. (2002). A multilocus gene genealogy concordant with host preference indicates segregation of a new species, Magnaporthe oryzae, from $M$. grisea. Mycologia, 94(4), 683-693. 
Fauziah, F., \& Rohdiana, D. (2016). Kompatibilitas jamur entomopatogenik paecilomyces fumosoroseus dengan beberapa bahan aktif pestisida secara in vitro. Jurnal Agro, 3(2), 1-7.

Herlinda, S., Mulyati, S. I., \& Suwandi. 2008. Jamur entomopatogen berformulasi cair sebagai bioinsektisida untuk pengendali wereng coklat. J. Agritrop. 27(3), 119-126.

Irawati A. F. C., Hartati, S., \& Windriyati, R. D. H. (2014). Pemanfatan cendawan endofit dalam meningkatkan kualitas bibit tanaman padi. Buletin Pertanian Perkotaan, 4(2), 30-40.

Oktariana, Wijaya, I., \& Sigit W., F. (2012). Pembiakan jamur entomopatogen Paecilomyces fumosoroseus dalam formulasi granula sebagai agensia hayati pada kutu kebul (Bemisia tabaci Genn.). Jurnal Fakultas Pertanian Universitas Muhammadiyah Jember, 1-11.

Paul, N. C. (2007). Diversity of endophytic fungi of medicinal plants in Korea and their antifungal and plant growth promotingactivity (Master thesis, Chungnam National University, Daejeon, Republic of Korea).

Sainul, A., Taufik, M., Gusnawaty, H. S., Khaeruni, A., Hasid, R., Bande, L. O. S., \& Botek, M., (2019). Peran cendawan endofit dan pupuk anorganik dalam meningkatkan produksi dan ketahanan padi gogo terhadap penyakit blas (Pyricularia oryzae). J. Berkala Penelitian Agronomi, 7(1), 16-22.

Sari, N. Y., Ete, A., \& Usman, M. (2017). Respon pertumbuhan padi gogo lokal yang diberi bahan organik pada berbagai kondisi ketersediaan air. e-J. Agrotekbis, 5(1), 5357.

Scheuermann, K. K., Raimondi, J. V., Marschalek, R., Andrade, A. D., \& Wickert, E. (2012). Magnaporthe oryzae genetic diversity and its outcomes on the search for durable resistance. The Moleculer Basis of Plant Genetic Diversity, 331-356.

Silitonga, T. S., Somantri, I. H., Daradjat, A., \& Kurniawan, H. (2003). Panduan Sistem Karakterisasi dan Evaluasi Tanaman Padi. Bogor: Badan Penelitian dan Pengembangan Pertanian Komisi Nasional Plasma Nutfah.

Siregar, H. (1981). Budidaya Tanaman Padi di Indonesia. Jakarta: Sastra Hudaya.

Soemartono, Bahrin, Hardjono, \& Iskandar. (1994). Bercocok Tanam Padi. Jakarta: CV. Yasaguna.

Sucipto, I., Munif, A., Suryadi, Y., \& Tondok, E. T. (2015). Eksplorasi cendawan endofit asal padi sawah sebagai agens pengendali penyakit blas pada padi sawah (Exploration of endophytic fungi from lowland rice as a biocontrol agent of blast disease in lowland rice). J Fitopatol Indones, 11(6), 211-218.

Taha, S. M., Mahmoud, S. A. Z., El-Damaty, A. H. \& Abd El-Hafez, A. M. (1969). Activity of phosphate-dissolving bacteria in Egyptian soils. Plant and Soil, 31, 149-160.

Yuliani, D., \& Maryana, Y. E. (2014). Kinerja penggilingan padi kecil di lahan kering Kecamatan Lempuing Jaya. Paper presented at Prosiding Seminar Nasional Lahan Suboptimal, Palembang, Indonesia. Retrived from http://repository.unsri.ac.id/ 10542/1/PROSIDING_SEMNAS_POLA.pdf 